\title{
KOMUNIKACIJA
}

\section{PAVELDO KOMUNIKACIJA SEIMO INTERJERE: ŽENKLŲ ATRANKOS, KŪRIMO IR PATEIKIMO PROBLEMOS}

\author{
Doc. Dr. ANDRIUS VAIŠNYs
}

Vilniaus universiteto Komunikacijos fakultetas

Vilnius university Faculty of Communication

Sauletekio al. 9, LT-10222 Vilnius

El paštas andrius.vaisnys@kf.vu.lt

\section{Santrauka}

Parlamentarizmo ideja turi ne tik turini - kaip ir kiekvienos kitos prasmei paliudyti, tradicijai atskleisti, reikalinga ir forma. Ten, kur demokratija - kad ir skirtingo modelio - trunka ilgai, parlamentu aplinka jų lankytojams būna ịdomi kaip muziejus, nes iš tikruju ji "transliuoja“ valstybingumo istorija, pasakoja apie tradicijos kūrejjus, suteikia galimybę atskleisti visuomenés savimonę ir santykị su demokratija.

1990 metais paskelbus Nepriklausomybę parlamento rūmuose, statytuose 1976-1980 metais, ju aplinkos ir interjero erdves, kurios paprastai turi skleisti institucijos istorija ir santvarkos dvasia, kito palyginti letai. Pastatas, iškilęs XX a. 9 dešimtmečio pabaigoje, buvo skirtas Lietuvos Soviety Socialistinés Respublikos (SSR) Aukščiausiajai Tarybai - per metus sušaukiamai 2-3 kartus ir imituojančiai parlamentarizmą. Iš tikruju kasdienybeje tai buvo Aukščiausiosios Tarybos Prezidiumo ir ji aptarnaujančio „aparato“ administracinis pastatas. Tad architektu Algimanto ir Vytauto Nasvyčiu sumanymas atitiko užsakyma: pagrindine foje pagal simetrini laiptiniu, igilinto cokoliniame aukštyje parodu „kambario“, drabužinès išdèstyma galejo priminti teatro aplinką. Pagrindinis puošy- 
binis elementas - Kazimiero Morkūno sukurtas vitražas „Švente்“. Kai kur sienos buvo "paženklintos“ vadinamosios tarybines dailes paveikslais - „socialistinio realizmo“ kūriniais, būtiniausiose vietose - Lietuvos SSR atributika: herbas su penkiakampe žvaigžde, raudona-balta-žalia ir raudona véliavos. Pirmieji pokyčiai prasidèjo Sajūdžio laikotarpiu, kai buvusi SSR Aukščiausioji Taryba ịteisino („sugrąžino“) trispalvę véliavą. Savanoriu užimtos gynybinès pozicijos ir gyventoju budejimas ties pastatu 1991-uju sausi, ginant valdžia nuo galimo sovietų kariuomenès puolimo, kuriam laikui neiprastai pakeite išorinę aplinka - atsirado barikados, vèliau, 2004 m., paverstos paminklu. Tik 1997 m. buvo pradetas rengti tuo metu vadinamu pirmujų rūmu interjero planas, kad parlamento sienos galetu skleisti Lietuvos Seimo tradiciją. $2002 \mathrm{~m}$. Seimo kanceliarija $i$ interjero koncepcijos parengima įtrauke istorijos specialistus. Straipsnyje bus aptarta, kaip buvo kuriamas dabartinis parlamento rūmu interjeras, išnagrinejant, kokie veiksniai lèmè sprendimus pasirenkant tuos ženklus Lietuvos raidoje, kuriais yra žymima parlamento istorija. Autorius taip pat atskleis sprendimy priemimo problemas ir požiūrị $i$ Seimo interjero kisma bei jo perspektyva, i parlamentinio paveldo komunikacija - kaip vizualaus naujo dokumentinio kūrinio atsiradima.

Reikšminiai žodžiai: interjeras; komunikacija; koncepcija; parlamentarizmas; paveldas; vizualumas.

Kas turètų formuoti Seimo istorijos interjerą parlamento rūmuose? Šis klausimas turi idejos ir dvasingumo pamatą - jis menkai susijęs su architektams būdingu požiūriu ị esminę pastato funkciją, suformuluojamą užsakymo metu, ir su vèlesniu siekiu rūpintis sienų apdailos priežiūra, pagal projektą suteiktų spalvų tęstinumu vykdant pastato remonto darbus, juolab - mažaja architektūra.

Ieškoti atsakymo teko Seimo kanceliarijai 1997 m., kai viename iš Seimo valdybos posėdžių Seimo spaudos tarnyba suformulavo problemą, kad parlamento lankytojams pastato aplinka neskleidžia istorinès 
informacijos, ir pasiūle leisti kurti, remiantis istorijos šaltiniais, planą, kuris padètų formuoti interjerą. Iš tikrųjų toks tikslas išplètė minètai tarnybai priskirtas viešųjų ryšių funkcijas, nes pagrindiniai uždaviniai buvo ir yra susiję su visuomenès informavimu apie aktualius parlamento veiklos dalykus. Vis dèlto komunikacijos filosofija leidžia kiek plačiau vertinti ryšių su visuomene darbo organizavimą: jei jau turime kurti pranešimus, tai turime suvokti, kas tai yra pranešimas apie parlamentą, iš parlamento, parlamente. Juk tai yra ne tik tekstinis pranešimas žiniasklaidai, bet ir paveikslas fojè arba vizualus žinių projektas, kuris suteikia atitinkamos informacijos parlamento lankytojui.

Valstybès santvarkos ir visuomenès sąmonès pokyčiai, atsivèrusi laisvè reikšti mintis skatino peržiūrèti visuomenès ir valdžios santykį, atversti anksčiau draustus skaityti arba atkurti „ištrintus“ istorijos puslapius. Lietuvoje Sąūdžio metais palyginti greitai, naudojantis šalies ir užsienio šaltiniais, pasklido naujos ir išsamios žinios apie valstybès dramą 1938-1940 m., gyventojų naikinimą 1941-1949 m. ir vẻliau, pasipriešinimo judejjimus. Žinoma, didžiausią susidomèjimą kèlè Pirmosios Respublikos gyvenimas tarp dviejų pasaulinių karų - pagaliau išnyko bet kokie draudimai ne tik susipažinti su archyvais, bet ir aktyviai ieškoti, kaupti, pateikti bet kokią informaciją, kuri galejjo papildyti to laikotarpio politinès, ekonominès, kultūrų raidos puslapius. O buvusios Lietuvos Respublikos politika, dažniausiai istoriografiniuose šaltiniuose siejama su vykdomosiomis valdžiomis, gana menkai rodo ịstatymų leidžiamosios valdžios vaidmenį. Viena vertus, tam reikšmès turẻjo 1926-1927 metų perversmas, sisteminè prezidentinès valdžios propaganda ir tai, jog 1927 m. balandžio 12 d. paleidus III Seimą, tikriausiai buvo sunaikintas parlamento archyvas. Kita vertus, politikos istoriją liudijantys fondai taip pat reikalavo pertvarkos ir naujo požiūrio ne tik ị sąvokas, bet ir i atsiveriančio dokumentinio paveldo vietą šiuolaikinejje visuomeneje. Tai, kad nuo 1990 m. iki 1997 m. Lietuvos parlamento rūmų sienos nerodė jokių parlamentarizmo tradicijai būdingų ženklų, juk nereiškia, kad tik XX a. pabaigoje prasideda Seimo istorija. Klaidingą „baltos dèmès“ isspūdị ga- 
lëjo sudaryti ịsivyravęs požiūris, jog apskritai politikos istoriją, dabartị ir perspektyvą galima nagrinèti nevaržomai kaip vyksmą, o „neutrali“ aplinka tiesiog yra dalykinès veiklos liudijimas. Tačiau politika - valstybès kūrimo menas, taip pat turinti paveldo bruožų, kuriuos gali išryškinti dokumentai, daiktai ir pasirinktas žmogaus veiksmas arba viso gyvenimo aprašymas. Svarbiausia būtų suprasti, kokiais kriterijais remdamiesi galime paveldą nustatyti ir ji parodyti.

Parlamento samprata dera su visos modernios Lietuvos istorija - nuo viduramžių iki naujausių jos puslapių. Ir jei praeityje matome ištrintus ženklus, tarp jų irgi, deja, liko Seimo veikla. Tačiau apie praeities parlamentą kartais galime svarstyti kaip apie dvasinị reikalą - ypač narstant Lietuvos Didžiosios Kunigaikštystès gyvenimą: juntama idejja, aptinkami pèdsakai, bet sudètinga sudèlioti vaizdą. Tai lemia pastatų, dokumentų, daiktų, biografijų trūkumo problema. Galètume pradèti nuo mūsų svarbiausio miesto, apie kurị Vladas Drèma parašęs, kad likimas „pašykštèjo tokios harmoningos istorinès tèkmès“, nes esą "Lietuvos sostinè karo kelių susidūrimo mazge“1. Suvokiant, jog kiekviena sostinè - valdovų ir vadovų gyvenimo, sprendimų prièmimo, tarptautinių ryšių centras, turètų liudyti valstybės ir visuomenès santykių ženklus, jų praradimai yra skaudūs, nors ir „ateina naujos kartos su naujais interesais, naujais gyvenimo reikalavimais, naujais estetiniais kriterijais“, bet vargu ar galinčios teigti, kad „nuosekliai ir harmoningai perimamos estetinès vertybès“2. Galime rasti atsakymą, kas galètų vykdyti uždavinị - pavyzdžiui, sukurti vaizdo pasakojimą apie parlamentą. Tačiau kaip tai reikètų padaryti iš kur surinkti reikalingas detales ir pateikti pasakojimą, kuris atskleistų reiškinio esmę ir vaidmeni - dar svarbesnis klausimas. Žinoma, toliau verta suformuluoti atsakymus ị klausimą, „kodèl“ pasirenkami kaip esą „tinkami“ vieni dalykai, kiti - atmetami.

Paveldo komunikacija reikalauja požiūrio ị daiktą, dokumentą tam tikrame kontekste, kitaip tariant - kad jis būtų „ịrèmintas“ vizualaus pa-

1 Drèma, V. Dingęs Vilnius. Vaga, 1991, p. 16.

2 Ten pat. 
teikimo kūrinyje. Būtent tokį naują kūrinị turime minty, kalbẻdami apie parlamento rūmų interjerą: jis turi turèti istorinių faktų pamatą ir kartu virsti pasakojimu, kuris spinduliuoja socialinę patirtị. Toks kūrinys turi suteikti žiūrovui galimybes ne tik suprasti ivvykius ar asmenybes, suvokti tam tikrą reiškinị, bet ir interpretuoti pagal savo patyrimą bei išsilavinimą. Vadinas, paveldo komunikacijoje reikia ne tik daiktų ir šaltinių, dar ir atitinkamų žinių, kad būtų galima pateikti atitinkamą pranešimą - kitaip tariant, išmanymo konstruojant minètą kūrinį.

Antai muziejininkas, rodydamas 1921 metų Aleksandro Stulginskio nuotrauką, pasako: „Štai valstybès Prezidentas“. Negana, dar ir parašą yra padejęs po nuotrauka ekspozicijoje. Ištiesdamas ranką i tą daiktą sakau: „Netiesa, čia yra Steigiamojo Seimo Pirmininkas, o ne Prezidentas“, nes taip galima spręsti iš ịvykio datos, kitų dalyvių ir vietos. Kitu atveju beveik nežinoma asmenybè - tarkime, Antanas Bulionis, peržvelgtas parlamento istorijos požiūriu, tampa neatsiejama jos dalimi. Reikalinga tam tikra informacijos kaupimo tvarka, kad tai, kas išsklaidyta ịvairiuose fonduose, būtų galima surinkti pagal naują paveldo žinių modelį, ir atsirastų naujas duomenų bankas, šiuo atveju - tinkamas kūrybiškai pateikti Lietuvos parlamentarizmo tradiciją.

Be to, kalbėdami apie naują paveldo komunikacijos kūrinị, turime perprasti vizualumo principus - vaizdo ịtaigą, vientisumą, logiką. Ir vèl turime kitą dilemą - koks turi būti vaizdas, kad atrinkti daiktai, dalykai padètų pagrịsti minètus principus. Vizualumo kultūros teoretikas Williamas J. Thomas Mitchellas pabrèžia, kad išradingas fotografijos, aliejinės tapybos, dirbtinès perspektyvos, skulptūros liejimo, interneto, rašymo, mimikrijos pateikimas savaime suteikia progų atkreipti dèmesį, kaip nauju būdu vaizdais pažymimas istorinis persilaužimas - tiek geras, tiek blogas ${ }^{3}$. Ir norèdami sukurti naują vaizdą, naudodami tam tikras pasirinktas priemones ir būdus, turime ji tarsi „pamatyti“ iš anksto. Tad toliau buvo (ir tam tikru aspektu lieka) svarbu atlikti paveldo konstravimo veiksmus.

3 Mitchell, W.J.T. Showing seeing: a critique of visual culture. Journal of visual culture. 2002, vol. 1, p. 173. 
Aplinkos inventorizavimas suteikė galimybę atsakyti i kitus klausimus:

- Kokie ir kur yra parlamentarizmo ir Seimo istorijos šaltiniai, kuriais remiantis galima formuoti interjerą;

- Kas galètų būti projekto autoriai arba bendraautoriai;

- Kaip pateikti Lietuvos parlamentarizmo istorijos ženklus (atsižvelgiant i laikotarpius ir temas, kurie galëjo kelti, kèlè, sukelia diskusijų ir kurie yra palyginti aiškūs faktų reikšmingumo aspektu).

Pirmiausia paaiškejjo, kad pagal vienodą koncepciją pateikti viso Pirmosios Respublikos laikotarpio nepavyks: ir kairès, ir dešinès politikai linkę savaip interpretuoti istorijos ịvykius, nors logiška būtų manyti, kad jokių neigiamų pasekmių vizuali medžiaga XX a. pabaigoje negalètų šiuolaikinèms politinėms jègoms turèti. Viduramžių Lietuvos parlamentarizmo ịprasminimas iš pradžių buvo atidètas "antram etapui“ (nuo 2002 m.) dèl tikslios ir išsamios informacijos trūkumo. Antra, sudètingesnè problema buvo ta, kad Lietuvoje parlamento tyrimų apskritai nebuvo vykdoma - tai rodo ir iki $1997 \mathrm{~m}$. parengtos mokslinès publikacijos, îvardytos žinyne „Lietuvos Respublikos Seimas 2000-2004“4, vèliau papildant kiekviename naujos kadencijos žinyne. Seimo kanceliarijos Informacijos analizès skyrius turejo parengtą studiją apie 1990-1997 m. laikotarpi ${ }^{5}$. Tad šios aplinkybès lėmė ir trečią problemą: nė viena mokslo ịstaiga nesutiko savarankiškai parengti gaires, kuriomis būtų galima vadovautis kuriant interjero koncepciją (Lietuvos istorijos institutas tik 2002 m. sutiko įvertinti jau parengtą planą ir ji papildyti bei patikslinti). Reikia pabrèžti, jog ir Seimo kanceliarija nekaupe istorijos dokumentų, išskyrus teisès aktų projektus ir priimtų teisès aktų originalus ${ }^{6}$. Atsakingai pasielgè valstybinių atminties institucijų vadovai ir/arba darbuotojai. Lietuvos nacionalinio muziejaus direktorè Birutė Kulnytė, Vytauto

4 Knygos apie Lietuvos parlamentą. Lietuvos Respublikos Seimas 2000-2004. Vilnius, 2001, p. 9.

5 Parlamentarizmo raidos etapai Lietuvoje. 1990-1997 m. Vyresn. konsultantas Alvidas Lukošaitis, 1997 m. sausio 24 d.

6 Kiek išsamiau tai aptarta: Vaišnys, A. Parlamento santykis su archyvu. Parlamento studijos. 2011, Nr. 11, p. 47-61. 
Didžiojo karo muziejaus skyriaus vedèja Audronè Veilentienè, Lietuvos centrinio valstybès archyvo Kino ir fotodokumentų skyriaus specialistai sutiko bendradarbiauti suteikdami galimybę susipažinti su turima šių isstaigų fonduose medžiaga. Žinoma, susipažìstant su dokumentais jau reikejo turèti interjero rengimo pirmo etapo juodraštị, kuriame atsispindejo Steigiamojo Seimo, I-IV Seimo vadovų pavardès, galimi pagrindinių ivvykių ir dokumentų pavadinimai. Tai suteikẻ galimybę $1997 \mathrm{~m}$. „atidaryti“ XX amžiaus Seimo pirmininkų fojè (I rūmai, 2 a.), atlikti kai kuriuos kitus parengiamuosius darbus - įskaitant tarybinès dailès kūrinių grąžinimą Lietuvos dailès muziejui ${ }^{7}$. Baltojoje salèje (dabar - Algirdo Mykolo Brazausko, I rūmuose, 2 a.), ịrengus parodų stendą, pradètos eksponuoti parlamento vadovybei įteiktos užsienio valstybių, vyriausybių, parlamentų vadovų dovanos.

Sukaupus pastatų istoriją, jų erdvių junginį teko apmąstyti kaip vientisą parlamento pastatų ansamblị, nors kelis visiškai skirtingus pastatus apibūdinti „ansambliu“ nèra labai objektyvu dèl architektūrinès dermès trūkumo ${ }^{8}$. Istorinị interjerą formuoti buvo numatyta palaipsniui - pirmiausia susitelkiant ties I ir II rūmais, nes juos užtvindo pagrindinis lankytojų (oficialių svečių, žurnalistų, ekskursijų) srautas.

Nors iš pradžių interjerui kurti reikalingos medžiagos ieška, atranka nebuvo pripažinta kaip reikšminè ryšių su visuomene funkcija, vis dẻlto interjero plano pirma redakcija buvo parengta jau $2000 \mathrm{~m}$. Ką ji apėmè?

Darbo tikslas buvo grindžiamas nuostata, kad Lietuva yra Didžiosios Kunigaikštystès paveldo puoselètoja, todèl ir Seimo tradicijos ištakos turi žymėti bent jau Ponų tarybos laikotarpi (XV a.). Tačiau iš pradžių nutarta pateikti Seimo I rūmų interjere tuos ženklus, kurie atspindi XX a. parlamento istoriją ir nesukelia nei mokslininkų, nei juolab politikų prieštaravimo:

7 Seimo ryšių su visuomene strategija 1998 m. Seimo kanceliarijos archyvas. F. 2, ap. 9 , b. 900 .

8 Pastate šalia Neries upès sovietmečiu buvo įkurdinta Finansų ministerija (dabar - vadinamieji Seimo II rūmai), o kitame, šalia Nacionalinès Martyno Mažvydo bibliotekos - Profesinių sajungų centro taryba (dabar - III rūmai). Po Nepriklausomybės paskelbimo, paverčiant parlamentą nuolat veikiančia institucija, prie pagrindinių, 1980 m. pastatytų rūmų, buvo prijungti minèti du pastatai. 
- I aukšte fojė grindinyje (itterpiant plokštę arba kitaip) numatyta ìspausti 1920 metų gegužès 15-osios deklaraciją (laikinai jos tekstas iškeltas virš pagrindinių durų - ir iki šiol šioje vietoje yra); priešais pagrindines duris skirta vieta svarbiam istorijos ženklui (tuo metu toje vietoje buvo tik viena arba kelios trispalvès vèliavos), ant kolonos dešinèje pakabintas Kovo 11-osios aktas; pagrindinès fojè nišos skiriamos 1905-ųjų - Didžiojo Vilniaus Seimo metų - nuotraukoms: procesija ir vaizdas iš/arba ị dabartinių Seimo rūmų vietą. Atsižvelgiant ị aukštingumą ir galimybę panaudoti galerijų sienas vizualiai informacijai, pasirinktos dvi nuotraukos, liudijančios $1991 \mathrm{~m}$. sausio mèn. situaciją ties pastatu. Ten pat paaiškinta $1991 \mathrm{~m}$. sausị paleistų šūvių aplinkybė ir pažymètas popiežiaus Jono Pauliaus II apsilankymas.

- II aukšte fojè kairiojoje dalyje, atsižvelgiant ị Baltosios salès paskirtị priimti oficialius parlamento svečius, skirta informacija užsienio lietuvių rengtiems seimams kovojant dèl Lietuvos Nepriklausomybės pripažinimo (pasirinkta Seimo Niujorke nuotrauka), Steigiamojo Seimo moterų frakcijos nuotrauka, Steigiamojo Seimo (1920 m.) Pirmininko portretas. Galerijoje tarp dešinès ir kairès nutarta išdèstyti parlamento svečių (pirmųjų asmenų) portretus. Dešinėje dalyje - kaip jau buvo minèta - pateikti XX a. Seimo vadovų portretai (pradedant I Seimu - Leono Bistro, ten pat - Vytauto Landsbergio, Algirdo Brazausko, Česlovo Juršėno). V. Landsbergio ir A. Stulginskio portretai pateikti vienoje galerijos ašyje - susiejant simbolinius Steigiamojo Seimo ir 1990-1992 metų Aukščiausiosios Tarybos-Atkuriamojo Seimo vaidmenis.

- III aukštas skiriamas išsamesniam istoriniam parlamento dokumentų ir įvykių pateikimui ${ }^{9}$.

Tuo metu Didžioji konferencijų salè neturejjo jokių ženklų, galinčių informuoti, jog ten 1992 metais buvo pasirašyta referendumu priimtoji

9 Seimo interjeras. Istorinès aplinkos kūrimo koncepcija, 2002. Seimo kanceliarijos archyvas. F. 2, ap. 9, b. 992. 
Konstitucija. Seimo spaudos tarnyba surinko dokumentus, susijusius su Konstitucijos rengimu, ir pasiūlè ịrengti atitinkamą ekspoziciją. Seimo Pirmininkas V. Landsbergis siūlè salei suteikti Konstitucijų pavadinimą, bet po diskusijų liko pagamintas užrašas „Konstitucijos sale““. V. Landsbergio iniciatyvai priklauso ir dar dvi vizualumo idejos: I aukšto fojè pritvirtinti Jono Basanavičiaus posakị "Jei per mūsų darbus Lietuvos dvasia atsikvošès - tąsyk mums ir kapuose bus lengviau ir smagiau ilsètis“, o plenarinių posėdžių salèje užrašyti: „Čia atkurta Lietuvos valstybë“.

Pavadinimus taip pat vertinant kaip svarbius ženklus, pirmame interjero plane buvo numatyta antrame aukšte buvusiai konferencijų salei Nr. 209 suteikti Lietuvos Tarybos pavadinimą (įrengiant ekspoziciją apie 1917-1918 metų instituciją, kuri pasirašytame Vasario 16-osios - Nepriklausomybės Akte - ịsipareigojo ir ịpareigojo Lietuvą sušaukti Steigiamąji Seimą, prièmusị lemtingus valstybès santvarkai, ūkiui, diplomatijai, žmogaus teisėms sprendimus), plenarinių posėdžių salei suteikti Kovo 11-osios salès pavadinimą ir atitinkamai I rūmams suteikti Kovo 11-osios rūmų pavadinimą, II - Seimo kanceliarijos pavadinimą, III Seimo komitetų rūmų pavadinimą.

2001 m. „Valstybès žinių“ leidyklai išleidus autorinị darbą - knygą

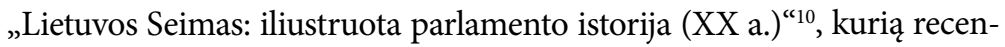
zavo istorikai Alfredas Bumblauskas ir Algirdas Jakubčionis, Seimo vadovybė ir Seimo kanceliarija pripažino poreikị nuosekliai rūpintis interjero aplinka. Pirmojo Seimo rūmų interjero plano parengimas padejo ịvertinti ir išgryninti ikonografinès medžiagos pateikimo ypatumą: atrodé, kad geriausias vaizdinys Seimo interjere turètų būti nespalvota fotografija, rašytinio (spausdintinio) teksto atvaizdas ir galbūt grafika. O paminètos knygos kūrimas paskatino žvilgtelèti kiek plačiau ị istorinio sąmoningumo ir valstybingumo ipprasminimo problemas Lietuvoje: juk svarbios reikšmès turi ir tai, kokie ženklai, vardai, pavadinimai supa svarbias valstybès institucijas, kitaip tariant - kas yra jų prieigose, ne vien viduje.

${ }^{10}$ Lietuvos Seimas: iliustruota parlamento istorija (XX a.). Sudarytojas ir apžvalg. str. aut. A. Vaišnys. Vilnius: Seimo leidykla ,Valstybės žinios“, 2001, - 112 p. 
$2002 \mathrm{~m}$. Seimo valdybai buvo pateikti kartu su Lietuvos istorijos institutu parengti pasiūlymai - „Žymiausių Lietuvos parlamentarų ir su Lietuvos Seimu susijusių ivykių jamžinimo koncepcija“, kuri yra publikuota leidinyje „Valstybingumo raidos atspindejimas Seimo interjere, parlamento aplinkoje ir paminklinėse sostinès vietose ${ }^{\text {"11 }}$. Koncepciją parašè mokslininkai Jūratė Kiaupienė, Edmundas Antanas Rimša, Alvydas Nikžentaitis, Gediminas Rudis, Ričardas Sirutavičius. Seimo valdyba, „atsižvelgdama ị Seimo kanceliarijos patirtị kuriant parlamentarizmo tradicijas atspindintị interjerą bei pritardama siūlymui ši darbą tobulinti“, prièmė sprendimą sudaryti Darbo grupę Seimo istorinės aplinkos interjero kūrimo darbams koordinuoti, kuriai vadovavo Seimo Pirmininko pavaduotojas Vytenis Povilas Andriukaitis ${ }^{12}$. Tai jau buvo svarus politinis sprendimas, atitinkąs ir kitose šalyse egzistuojančią praktiką. Seimo kanceliarijai buvo pavesta „2003 metais tinkamai sutvarkyti Seimo I rūmų reprezentacinių patalpų interjerą "13. Šis ịpareigojimas ịteisino ryšių su visuomene funkcijų išplètimą ir galimybę Seimo kanceliarijos Seimo ryšių su visuomene skyriui parengti artimiausių darbų planą, isskaitant Konstitucijos salès interjero pertvarkymą. Minèta koncepcija patvirtino, jog „eksponuojant Lietuvos parlamentarizmo tradicijas būtų politiškai ydinga apsiriboti tik XX amžiaus Lietuvos Respublikos Seimų istorija, kadangi toks požiūris demonstruotų, kad Lietuvos valstybejje lig šiol egzistuoja siaurai tautiškos istorijos <...> suvokimas“"14. Ši ekspertų pastaba - ịsigilinus ị akcentus - yra ne tiek patariamojo, kiek vertinamojo pobūdžio: mokslininkai, rengdami koncepciją, žinojo, kad Lietuvos Didžiosios Kunigaikštystès paveldo ženklų skverbtis ị Seimo rūmų in-

11 Valstybingumo raidos atspindejjimas Seimo interjere, parlamento aplinkoje ir paminklinése sostinès vietose. Sudarytojas Andrius Vaišnys. Vilnius: Seimo leidykla „Valstybès žinios“, 2004, p. 13-18.

12 Lietuvos Respublikos Seimo valdybos sprendimas Nr. 993, 2002 m. liepos 19 d.

13 Ten pat, sk. 3.

14 Valstybingumo raidos atspindejimas Seimo interjere, parlamento aplinkoje ir paminklinèse sostinès vietose. Sudarytojas Andrius Vaišnys. Seimo leidykla „Valstybės žinios“, 2004, p. 13. 
terjerą nepriimama vienareikšmiškai. Jau iš pavadinimo galima suprasti, kad koncepcijos turinyje buvo pateikti pasiūlymai, kokias asmenybes ir ivvkius derètų ipprasminti parlamento pastatų erdvėse. Kita vertus, greta Leono Sapiegos, Gabrielès Petkevičaitès, Albino Rimkos, kitų vardų, Gegužès 15-osios, Kovo 11-osios pavadinimų, susijusių su parlamentarizmu, buvo pateikta vardų ir pavadinimų, menkai su juo susietų - kaip antai, Martyno Mažvydo ir pan. Tai suteikè pretekstą naujai diskusijai minètoje darbo grupèje, juolab kad Seimo kanceliarija turèjo parengti planus, atspindinčius patalpų pavadinimus ir ikonografinès medžiagos išdèstymą. $2002 \mathrm{~m}$. lapkričio $4 \mathrm{~d}$. Seimo valdyba, susipažinusi su pakoreguotu Seimo istorinès aplinkos koncepcijos projektu, prièmė sprendimą Darbo grupei Seimo istorinès aplinkos interjero kūrimo darbams koordinuoti darbą tęsti ir Seimo istorinès aplinkos koncepcijos projektą pateikti Seimo komitetų pirmininkams, Seimo frakcijoms susipažinti, kad pateiktų pastabas ${ }^{15}$. Pastabų iš komitetų ir frakcijų darbo grupè nesulaukè. Galiausiai darbo grupé, vadovaudamasi Seimo valdybos sprendimu, ịpareigojo Seimo ryšių su visuomene skyrių dar kartą peržiūrèti „Žymiausių Lietuvos parlamentarų ir su Lietuvos Seimu susijusių ịvykių jamžinimo koncepciją" ir patikslinti ją taip, kad liktų tik aiškiai „susiję ivvykiai“" ir vardai.

Iš esmès per vienerius metus pavyko ne tik baigti surinkti naują ikonografinę medžiagą, parengti reprezentacinių patalpų planus, bet ir dalị sumanymų ịdiegti - išskyrus vieną, susijusị su Konstitucijos sale.

Dar 2000 m. padarius išvadą, kad pirmo Lietuvos Statuto kūrèjui Albertui Goštautui pristatyti nèra išlikusio jokio tinkamo vizualiai panaudoti piešinio ar panašaus dokumento - nei Lietuvos, nei Lenkijos archyvuose - dailininkè scenografé Janina Malinauskaité, istorinių veikèjų tapytoja, sutiko sukurti A. Goštauto „viziją“. 2003 metais Seimo valdybos darbo grupé surengė paveikslo sutiktuves ir pripažino, kad tokio pobūdžio darbas gali būti vertinamas kaip išimtis visame parlamento rūmų

${ }^{15}$ Seimo valdybos $2002 \mathrm{~m}$. lapkričio 4 d. posėdzio protokolas Nr. 208. 
interjere. Tačiau netrukus darbo grupei kai kurie dailininkai ir politinio pasitikèjimo valdininkai pasiūlè parlamento interjerui užsakyti tapybos darbų ciklą - valstybės veikèjų portretus, istorinių îvykių scenas. Ar naujos tapybos - tarsi gamybos įmonejje pagal būtinų pagaminti produktų sąrašą - procesas būtų pateisinamas ir tie „produktai“ galètų tinkamai puošti sales? Šis klausimas lėmė naują diskusiją tarp Seimo kanceliarijos, minètos darbo grupès, kai kurių politikų ir, žinoma, sumanymą teikusių dailininkų. Ši diskusija laikinai sustabdè sumanymą pertvarkyti Konstitucijos salès interjerą panaudojant dokumentines ịvykių fotografijas, nes būtent šiai salei buvo siūloma nutapyti didelių formatų drobes. Savotišku „pavyzdžiu“ - kokie ne tiek dèl dydžio, kiek dèl lygio bei turinio darbai ten būtų galèję atsidurti - tapo dailininko Antano Beinaravičiaus paveikslas „Žalgirio mūšis“, kurio sutiktuvès Seimo valdybos sprendimu buvo surengtos $2004 \mathrm{~m}$. kovo $11 \mathrm{~d}$. Seimo ryšių su visuomene skyrius rekomendavo šio paveikslo Seimo rūmų interjere atsisakyti pirmiausia dèl turinio, kuris „nesusijęs su parlamentarizmu“, taip pat - pasiremiant kompetentingų dailès kritikų nuomone - ir dèl abejotinos meninès vertès. Ir nors paveikslas buvo perkeltas ị Krašto apsaugos ministeriją, Seimo kanceliarijai $2005 \mathrm{~m}$. vis dèlto teko imtis tapybos darbų konkurso parlamento istorijos tematika ${ }^{16}$. Kanceliarija vertinti darbus apdairiai patikejjo žiuri, sudarytam iš profesionalių dailètyrininkų, kritikų, dailininkų (konkursiniai pasiūlymai buvo priimami Lietuvos dailès akademijoje). Konkurso baigtis - joks pasiūlymas nerekomenduotinas igyvendinti (tokią išvadą lèmė ir tai, jog dailininkai esą menkai išmano istoriją,

16 „Kodèl dabar pasirinkote tapybq? - Nagi norèjome ,patikrinti“ dailininku

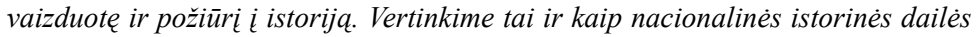
plètojima $<\ldots>$. Paskelbtame tapybos konkurse, skatinant dailininkus susidomèti istorija ir ja interpretuoti, nurodomos 4 temos: I Statuto priemimas, Abieju Tautu Respublikos 1791-uju Konstitucijos priemimas, pirmosios Lietuvos Respublikos Konstitucijos svarstymas ir priemimas $1922 \mathrm{~m}$. Steigiamajame Seime, $1992 \mathrm{~m}$. Lietuvos Respublikos Konstitucijos priemimas (galima suvokti ir kaip jos kürima, svarstyma, patvirtinima)“. Seimas ragina tapyti istoriją/Interviu. Literatūra ir menas. 2005, rugsejjo 30 . 
juolab - Lietuvos Seimo). Taigi tik 2006 m. Seimo Konstitucijos salèje buvo atidengtos 4 ispūdingo dydžio fotografijos, atspindinčios Steigiamojo Seimo rinkimų sceną, pirmuose visuotiniuose rinkimuose išrinktų narių dalyvavimą pagerbiant Nežinomojo kareivio kapą (1921 m.), Konstitucijos pasirašymą, Sausio 13-ąją Nepriklausomybès aikštėje. Ten pat naujai įrengtos pagrindinio įstatymo ir susijusių dokumentų, daiktų ekspozicijos, salè papuošta istorinèmis vèliavomis.

Suprantama, parlamento rūmai gali ir turi būti puošiami tais menininkų darbais, kurie atitinka rūmų paskirtị ir turi prasmès, remiantis paveldo komunikacijos, istorijos ir estetikos kriterijais. Kai 1998 m. rugsèjo 10-gruodžio 30 dienomis buvo surengta taikomosios dailès ekspozicija „Naujoji lietuvių tradicinè dailè naujojo šimtmečio išvakarèse“ per tris pirmų Seimo rūmų aukštus, kai kuriuos darbus Seimo kanceliarija įvertino kaip tinkamus papuošti aplinką - kaip antai Didžiajame kieme igyti ties pagrindinėmis Seimo durimis eksponuotą skulptorès Daliutės Onos Matulaitès kūrini „Gražina“. Seimo interjere atsirado ir dar keli šios autorès darbai - „Herbas ir himnas“, „Valstybininko stalas“, nors pastarajam Kovo 11-osios rūmuose reikalinga nuolatinè techninè priežiūra, nes jis turi funkcionuoti tarsi gyvas meninis organizmas, o ne buitinis dirbinys.

Išsamiau dera stabtelèti ties straipsnio izžangoje paminèta vitražo meistro K. Morkūno „Švente“. Jau šiame amžiuje dailininkas pasiūlè Seimo vadovams ir Seimo kanceliarijai pakeisti šią $180 \mathrm{~m}^{2}$ interjero detalę nauju kūriniu. Ir tik paaiškinus visiems suinteresuotiems nauju pasiūlymu asmenims, kad „Šventë“ yra paveldosaugos objektas ir jị išimant būtų nepataisomai sunaikintas, pakeitimo idejja atidèta. Be to, dailininkas yra siūlęs parlamento interjere vitražo kūriniais pavaizduoti kunigaikščius ir tris prezidentus - A. Stulginskį, Kazị Grinių ir Antaną Smetoną. Parlamento galerijoje buvo surengta šio pasiūlymo eskizų (piešinių) paroda. Dailininkui interjero koncepcijos rengejjai aiškino, jog Seimo interjeras pirmiausia turètų atspindèti parlamentarizmo tradiciją; vargu ar A. Smetona atspindi tokią tradiciją. Galiausiai $2010 \mathrm{~m}$. menininkas pateikè „Žalgirio mūšio“ vitražą, numatytą naujos Seimo posèdžių salès 
aplinkoje. Visiškai nekvestionuojant įžymaus dailininko sukurto kūrinio meniškumo, apie tematiką verta pasakyti: kūrinys atspindi „populiarųji‘ požiūrị pasirenkant neva vienintelị žinomą („reikšmingiausią“) valstybès istorijos įvykị. Apskritai „Žalgirio mūšį“ teikti valstybès institucijoms kaip svarbių politinių sprendimų ženklą yra būdingas dalykas - apie tai jau teko užsiminti.

2006 m. rugpjūčio mèn. buvo baigtas derinti tik ką paminètos Seimo posèdžių salès projektas, kuri yra pastatyta rekonstravus minètus antruosius rūmus. Diskusija - vieša ir nevieša - dèl Lietuvos parlamento posèdžių naujos salès statybos truko nuo 1999 m. Kuriant rūmų interjero koncepciją buvo numatyta tam tikrus pavadinimus, dokumentus pritaikyti iš dalies 2007 m. perstatytame pastate. Kai 2005 m., parengus salès poreikio argumentus, Seimo Pirmininkas pristatė Seimo nutarimo „Dèl Seimo posèdžių salès“ projektą ${ }^{17}$, kartu su architektais buvo derinami ne tik funkciniai reikalavimai, bet ir formavosi nuostatos, kokią vizualią informaciją būtų galima pritaikyti II rūmuose. Ten buvo numatyta sukurti Seimo kanceliarijos istorijos ekspoziciją, atnaujinti „Seimo kronikos" kavinę, parlamentinei žurnalistikai skirtą ekspoziciją, sukurti vizualią skaitmeninę Seimo sudèties informaciją (iki statybų ji buvo pateikiama kaip aplikacinis piešinys Spaudos konferencijų saleje). Kalbant apie Posėdžių salę, jos prieigose buvo numatyta kurti XXI a. parlamento priimtų svarbiausių aktų ir įvykių ekspoziciją. Tiesa, įdomu tai, kad naujo statinio autoriai atskleidè savitą parlamento sampratą per pirmąji projekto aptarimą, nes salëje siūlè svarbiausias vietas skirti ambasadoriams, ministrams, Prezidentui. Kitaip tariant, buvo galima ịsitikinti,

$17,{ }^{\prime}, \ldots>$ Seimo posédžiu sale nèra paprasta darbo vieta. Tai ne vien tik paprasta patalpa, tai ne tik formalus teisès aktu prièmimo, bet ir stiprus politiniu ideju centras. Čia aptariami ir čia Lietuvai skelbiami pagrindiniai sprendimai. Todèl šis centras, kaip yra kiekvienoje demokratinejje vakarietiškoje valstybeje, reprezentuoja tautos igaliojimu pirmuma, jos rinktu atstovu kolektyvinę ịtaka šalies valdymui, liudija istorijos tęstinuma“. Artūras Paulauskas. Lietuvos Respublikos Seimo nutarimo „,Dèl Seimo posėdžių salès“ projekto Nr. XP-865 pateikimas, svarstymas ir prièmimas, 2005 m. lapkričio 17 d. 
kaip parlamentinè valstybė, parlamentarizmas „funkcionuoja“ jo aprūpinimo kūrèjų - architektų ir inžinierių - sąmonèje. Būtent to posėdžio metu, dalyvaujant ir minètai Darbo grupei Seimo istorinès aplinkos interjero kūrimo darbams koordinuoti, pavyko ịtikinti projektuotojus „apsukti“ posėdžių salès išdèstymą 180 laipsnių kampu. Taip ir yra padaryta, tačiau iš tikrųų tik stiklas tapo naujos salès interjero dominante. Salès spalvos (ypač parlamentarų kẻdžių), kiti interjero elementai (išskyrus herbą) neliudija Lietuvos nacionalinio parlamento ženklų. Kaip su parlamento sprendimų prièmimu, jo istorija siejamas minètas „Žalgirio mūšio" vitražas, gali svarstyti patys Seimo nariai. Galbūt taip ịvyko dẻl to, jog Seimo Pirmininkas buvo ịvardijęs ịvairius reikšmingus reikalavimus politiniu, istoriniu, modernių technologijų, apšvietimo aspektais, kuriais būtų grindžiamas projektas, bet liko nepabrèžtas vizualus salès svarbiausios Lietuvoje sprendimų rengimo ir prièmimo vietos - ir jos aplinkos prasmingumas. Juolab kad „salès projekto autoriai, konstruktoriai, inžinieriai atsižvelgè i iškeltas sąlygas užtikrinti gerą informacijos, vaizdo, garso ryši parlamento viduje, taip pat, prireikus, ir vykstant bendriems posėdžiams su Europos Sąungos institucijomis, Europos Parlamentu“18. Tiesa, nuo salès statybos pradžios jau niekas iš paminètos darbo grupès nedalyvavo interjero įrengimo metu. Salès prieigose atsirado vietos kai kuriems skulptūriniams elementams, perkeltiems iš Kovo 11-osios rūmų.

Pozityvų vaidmenį formuojant parlamento istorinį interjerą ir išorinę pastatų aplinką lèmé kelių komisijų veikla - Steigiamojo Seimo 80-mečio minejjimo komisija (2000 m., pirmininkas Vytautas Landsbergis), Konstitucijų sukakčių minejjimo komisija (2002 m., pirmininkas Artūras Paulauskas), Valstybinè Didžiojo Vilniaus Seimo (Lietuvių suvažiavimo) 100-mečio sukakties, Steigiamojo Seimo pirmojo posèdžio 85-ųjų metinių ir Lietuvos Respublikos nepriklausomos valstybès atkūrimo 15-ųjų metinių paminejjimo komisija (2005 m., pirmininkas

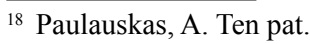


Česlovas Juršènas - tuo metu joje buvo diskutuojama ir apie LDK parlamentarizmo ištakas, formavimąsi, galimybes tai įamžinti), Lituanistikos tradicijų ir paveldo iprasminimo komisija (2003 m., pirmininkas A. Paulauskas; 2004-2008 m., pirmininkas Č. Juršènas) ${ }^{19}$. Jos padèjo igyvendinti idejjas, kurios Lietuvos parlamentarizmą, demokratijos tradicijos diegimą galejo paliudyti ne tik Seimo rūmuose, bet ir kitose Lietuvos vietose, suprojektuojant ir sukuriant atitinkamus ženklus:

- Paminklinė lenta Vilniaus konferencijai, išrinkusiai Lietuvos Tarybą 1917 m., Vilniuje, ant teatro pastato (2007 m.);

- Paminklinis bareljefas Ministrui Pirmininkui (1918 m.) Mykolui Šleževičiui (aut. Anicetas Vambutas) Vilniuje, Gedimino pr. (2006 m.);

- Plokštė su įrašu grindinyje Didžiojo Vilniaus Seimo vaidmeniui išryškinti Vilniuje, priešais Nacionalinę filharmoniją (2005 m.);

- Paminklas Didžiojo Vilniaus Seimo sumanytojui Jonui Basanavičiui (aut. Gediminas Jokūbonis) Nacionalinès filharmonijos rūmuose (2005 m.);

- Azžuolų alejja, sodinama Seimo pirmininkams (1920 m. - iki dabar) pagerbti priešais Seimo rūmus, Vilniuje, A. Goštauto gatvėje (2005 m.);

- Antano Tumèno - Konstitucijos (1922 m.) rengejo, gatvès pavadinimas Vilniuje, ties Seimo rūmais (2005);

- Konstitucijos prospekto pavadinimas Vilniuje (2002 m.);

- Paminklinè lenta I-III Seimams atminti ant dabartinès Maironio gimnazijos fasado Kaune (2002 m.);

- Steigiamojo Seimo aikštès pavadinimas Kaune (2002 m.);

- Irašo postamentas apie pirmajji Steigiamojo Seimo posèdi (1920 m. gegužès 15 d.) Kaune, prie Muzikinio teatro (2000 m.);

19 „Lietuvos Respublikos Seimas, atsižvelgdamas $\mathfrak{x}$ tai, kad Didysis Vilniaus Seimas suvienijo Lietuvos visuomenę, jo nutarimai turèjo didelę reikšmę Lietuvos valstybès atkūrimui ir padarè pradžia parlamentarizmui, kuri sutvirtino Lietuvos Steigiamasis Seimas ir toliau plètoja mūsu nepriklausomos Lietuvos valstybès Seimas, $n$ u t ari $a<\ldots>$ paskelbti 2005 metus Didžiojo Vilniaus Seimo ir parlamentinés tradicijos metais“. 2005 m. sausio 20 d. Lietuvos Respublikos Seimo nutarimas Nr. X-94. 
- Paminklinis akmuo Antanui Tumėnui Rokiškio r. (2002 m.).

Toliau kalbant apie paveldo konstravimą, dera pabrèžti, kad tai yra reikšminis formuojamos politikos ir politikos formavimo veiksnys. Juk galime turèti skirtingas parlamentinès tradicijos interpretacijas ir skirtingą paveldo komunikacijos rezultatą. Isaiahas Berlinas, nagrinèdamas XIX amžiaus nacionalizmą ir vẻliau kilusių iš jo judejjimo valstybių santvarkas, prisipažịsta norịs pabrèžti „,ideologiškai svarbesnị ir pavojingesnị dalyką: <..> žmonès priklauso tam tikrai grupei, <...> tą grupę sudarančių individų charakteriai yra suformuoti tos grupès ir be jos negali būti suprasti“ ${ }^{\text {“20 }}$. Jei norètume žiūrèti plačiau, parlamentarizmo idejos konstravimas pagal paveldo komunikacijos sampratas mums gali atverti duris skirtingų grupių sugyvenimo link. Ir būtent šiuo aspektu yra naudinga objektyviai parodyti visą parlamentarizmo patirti - ne tik 1920-1927 metų, bet ir įskaičiuoti IV Seimo (1936-1940 m.) veiklą, ir neabejotinai - Lietuvos Didžiosios Kunigaikštystès Seimo istoriją.

2002 m., minint Steigiamojo Seimo dieną, Parlamento galerijoje buvo pasitiktas istorinès vèliavos (Vyčio raudono audeklo fone) projektas ir istorinis Valstybès herbas, kurị sukūrè dailininkas Arvydas Každailis. Minint Lietuvos Konstitucijų (1922 ir 1992 m.) sukaktis sumanymas pateikti LDK ženklus ir įvesdinti juos ị viešąj Lietuvos gyvenimą buvo aptartas Seimo valdybos narių ir Heraldikos komisijos pirmininko Edmundo Rimšos. Istorinès vèliavos eksponavimas paskatino politikų diskusiją, kaip būtų galima ịteisinti jos naudojimą viešame gyvenime. $2004 \mathrm{~m}$. sausio 5 d. Seimo valdyba sudarè darbo grupę, vadovaujamą V. P. Andriukaičio, İstatymo „Dèl Lietuvos valstybès vèliavos“ pakeitimo istatymo projektui parengti. Šis teisès aktas, kuriuo buvo įteisinta ir istorinè valstybės vėliava, yra priimtas $2004 \mathrm{~m}$. liepos $8 \mathrm{~d}$. Nepriklausomai nuo ịpareigojimo Vyriausybei, bet ir nuo plačių galimybių visuomeninėms organizacijoms, savivaldybių ịstaigoms naudoti „raudonąją vèliavą" îvairiomis progomis, pirmuosius dvejus metus ši vẻliava puošè tik

${ }^{20}$ Berlin, I. Vienove ir ívairové: žvilgsniai i idèju istorijq. Amžius, 1995, p. 45. 
Seimo rūmus ir būdavo iškeliama gegužès 15-ąją - Steigiamojo Seimo dieną - Nepriklausomybès aikštejje. Dešimtmečio pabaigoje istorinè véliava, greta trispalvès, jau tampa papildomu valstybès įstaigų atributu.

Kitokios lemties sulaukè po minèto pristatymo istorinis („Didysis“) valstybès herbas, kurị Seimo valdyba leido naudoti kaip puošybinị elementą Seimo didžiojoje fojè. Argumentas istorinị herbą nuolat eksponuoti parlamento fojè buvo heraldikos elementai, leidę atrasti sąsają su LDK laikotarpiu. Suderinus su dailininku, ženklas buvo papildytas ịrašu „Lietuvos Seimas“ ir jo fone keletą metų būdavo pasitinkami oficialūs svečiai, nuotraukose issiamžindavo parlamento ekskursijų dalyviai. Originalūs nedidelio mastelio istorinès vèliavos ir minèto Didžiojo herbo piešiniai palikti Seimo ekspozicijoje Kovo 11-osios rūmų III aukšte. Nuo pat $1990 \mathrm{~m}$. Seimas neturejo įtaigaus ženklo, kuris aiškiai liudytų politinès institucijos vietą ne tik šiuolaikinèje valstybejje, bet ir prieš dešimtmečius ar galbūt šimtmečius. „Didysis herbas“ buvo bandomas pasiūlyti kaip alternatyva minèto I rūmų pastato kampinio vaizdo fragmentui, kurị laiką vaizduotam net oficialiuose dokumentuose.

Tačiau po kelių metų, dešimtmečio pabaigoje, LDK parlamentarizmo ir Didžiojo Vilniaus Seimo metų ženklai Seimo interjere ima „tirpti“. Pagal koncepciją viduramžių parlamentarizmui buvo skirtas vadinamasis „baltasis koridorius“ (1 a.) iš III ì pagrindinius rūmus, kuriame 2005 m. buvo pateiktas LDK žemèlapis su Seimų miestais ir datomis, Leono Sapiegos ir Radvilos Juodojo portretai. O pagrindinèje fojè specialiai pagamintuose ekspoziciniuose staleliuose buvo pateikti parlamentarizmo progoms išleisti sidabro bei kitokio metalo medaliai, kiti smulkūs daiktai. Ne tik minètasis LDK žemèlapis, bet ir „Didysis herbas“ jau yra iškelti (tikriausiai ị sandèlį). Atsakymų i klausimą, kodèl tai vyksta, pasitaiko ivvairių - nuo nuostabos („nejaugi išnyko“?) iki tariamų „argumentų“: esą „Didysis herbas“ neįteisintas (tarsi tam galių turètų kažkas kitas už parlamento ribų), galbūt „ne ta vieta“, gal reikètų kai ką atnaujinti „iš esmès“. Vis dèlto atsižvelgiant ị šaltinius, jog Lietuvos Seimo institucijai 
jau sukanka 500 metų $^{21}$, juolab neturètų būti galima „nubraukti“ LDK parlamentarizmo.

2012 m. Seimo vizitine kortele tapo trijų tautinių spalvų „amfiteatras“ su „imerktu“ XX a. trečiam dešimtmečiui būdingu stilizuotu Vyčiu.

Iš tikrųjų tai jau yra politinio požiūrio ị valstybès istoriją raiška: visa tai, kas vizualiai nepateikiama (nors galètų), nes galbūt „netelpa“, rodo LDK liberalios dvasios ir sudètinès mūsų paveldo dalies ignoravimą. Kita vertus, galbūt „nacionalinio parlamentarizmo“ pabrèžtis paverčiama istorijos priešybe ir tyčia uždaro Lietuvą naujausiuose laikotarpiuose. Ji gali atsirasti ir iš nenoro matyti aristokratiškojo elito parlamentus greta „paprastų žmonių“ parlamento istorijos. Galbūt LDK parlamentarizmo paveldą paliksime Baltarusijai, kuri juk kada nors taps parlamentine valstybe.

Dar reikètų priminti, kad 2007 m. Seimo valdyba atšaukė 2002-ųjų sprendimą dèl interjero kūrimo ${ }^{22}$, kuris bent du kartus iki tol - 2004 ir 2005 m., buvo tikslintas tik vienu - vadovavimo darbo grupei aspektu, nepildant ir neatšaukiant jo esminès dalies. Būtent tuo metu iš Baltijos Asamblëjos (BA) salès buvo pašalinta šios organizacijos simbolika, vèliava. BA liudijantys ženklai į minètą salę sugrąžinti tik $2012 \mathrm{~m}$. (minètoje interjero koncepcijoje tebėra numatyta, kad BA salèje galètų būti pateikti ir tarpukario Baltijos šalių bendradarbiavimo dokumentai). Kaip ir būdinga ịvairioms ekonomikos, kultūros, švietimo sritims, kintant valdžių sudètims ir valdininkijai, projektų ir idejjų tęstinumą išsaugoti nelengva ir tokiame svarbiame vizualiame kūrinyje kaip istorinis Seimo interjeras.

${ }^{21},,<\ldots>$ nauja $\{L D K\}$ parlamentarizmo kokybę liudija $<\ldots>$ seimu institucionalizacija: $1512 \mathrm{~m}$. pirmakart suformuluojama dvieju atstovu iš vienos žemès taisyklè, kuri nuo to laiko, nors ir nesistemingai, buvo taikoma vis naujoms teritorijoms, kol per 1564-1566 m. reformas nevirto istatymu“. Petrauskas, R. Nuo valdovo tarybos iki bajorų seimo: luominio atstovavimo institucijos atsiradimas. Lietuvos istorija. Baltos lankos, 2009, t. 4, p. 280.

${ }^{22}$ „Lietuvos Respublikos Seimo valdyba n u s p r e n d ž i a : Pripažinti netekusiu galios Seimo valdybos 2002 m. liepos 19 d. sprendimą Nr. 993 „Dėl Seimo istorinès aplinkos interjero“. Seimo Pirmininkas Viktoras Muntianas“. Seimo valdybos sprendimas ,Dèl Seimo valdybos 2002 m. liepos 19 d. sprendimo NR. 993 pripažinimo netekusiu galios“. 2007 m. gegužès 11 d., Nr. 1592. 
Seimo rūmai turètų atspindèti ir skleisti politikos santykių visumą - net ir tada, kai tam tikrų dalykų atsiranda ne tiek iš nuoširdaus poreikio, kiek vadovaujantis pažiūromis arba siekiant įteisinti visuomenei būdingų ženklų reikšmingumą. Antai $2000 \mathrm{~m}$. buvo pradètas projektuoti vadinamasis „Susikaupimo kambarys“, vèliau pavadintas Jono Pauliaus II vardu (III rūmų 1 a.). Ši patalpa formaliai įrengta $2001 \mathrm{~m}$., tačiau jos interjeras baigtas kurti 2006 m. Vis dèlto - kad ir kaip vertintume susikaupimui skirtos patalpos „naudingumą“, pasitaiko, jog jos paskirtis iškreipiama tikriausiai žeidžiant dalies žmonių (ịskaitant idejjos autorius) pažiūras: kartais patalpa paverčiama persirengimo kambariu, kartais - prekybos vieta ${ }^{23}$.

Sudètinè interjero kūrimo darbų dalis buvo Seimo istorijos dokumentų skaitmeninimas ir pateikimas parlamento svetaineje seimas.lt jau nuo 1999 m. ${ }^{24}$ Šiuo metu parlamentarizmo istorija yra pripažistama kaip studijų ir mokslo objektas; jos pateikimas svetainèje sudaro galimybę analizuoti - kaip būtų galima tobulinti Seimo interjero vizualų pateikimą.

\section{Išvados}

Paveldo komunikacijos požiūriu Seimo istorinis interjeras atsirado šiame amžiuje kaip naujas vizualus kūrinys, sudètas remiantis ịvairiais istorijos, politikos tyrimais ir dokumentų fondais, kurie tiesiogiai nebuvo nukreipti ị dominantị Seimo kanceliarijos darbuotojus ir parlamento vadovus objektą - parlamentarizmą. Išanalizavus ikonografinę medžiagą ir dokumentus, interjero dominante pasirinkta juodu-baltu atvaizdu rodoma fotografija, dokumentai; kitokių spalvų ar atspalvių vaizdai vertinami kaip išimtis (kai reikia pagrịsti daikto, dokumento kilmès išskirtinumą).

${ }^{23}$ Račiukaitis, A., Vaiseta, T. Koplytėlèje - akinių prekyvietė: ,Akiniai buvo išdèlioti šalia Rūpintojèlio“. Lrytas.lt. 2008, vasario 6, 07:22.

${ }^{24}$ Šią informaciją rinko ir sutvarkè - įskaitant parlamentarizmo asmenybių biografijas - Marius Gedutis, Aigustė Vykantė Bartkutè-Poderienè, Valdas Sinkevičius, Andrius Vaišnys, Artūras Zeleniakas, $2007 \mathrm{~m}$. interneto svetainèje ties autoriniais tekstais pavardès buvo ištrintos, nors iki $2002 \mathrm{~m}$. tai buvo savarankiškas kūrybinis darbas. 
Laikytasi požiūrio, kad interjere taikomojo pobūdžio daiktai ir dalykai yra kitų - dažniausia [turètų būti] nacionalinių [heraldikos] spalvų. Parlamentinès tradicijos paveldo konstravimas sudarė galimybę ne tik parengti „Žymiausių Lietuvos parlamentarų ir su Lietuvos Seimu susijusių ịvykių jamžinimo koncepciją“, bet ir lèmè sprendimus 2000-2006 m. j̇amžinti parlamentarus bei Lietuvos valstybei reikšmingus parlamento ịvykius ir kitose Lietuvos vietose, ne vien Seimo rūmuose - dabar tai dera ịvertinti kaip parlamentarizmo idejjos sklaidą. Tokių sprendimų kryptis galètų būti išlaikoma ir ateityje. Lietuvos Seimo rūmų istorinès aplinkos interjerui, nuo 1997 m. kurtam pagal specialistų koncepciją, šiuo metu trūksta vientiso istorinio ir komunikacinio požiūrio: kokia reikšmė teikiama Lietuvos Didžiosios Kunigaikštystès seimams, ar šiuolaikinis parlamentas pripažǐsta LDK elito parlamentinès ir kitos politinès veiklos vaidmeni, vertą demonstruoti darbo aplinkoje. Išskyrus Alberto Goštauto portretą ir $2004 \mathrm{~m}$. įteisintą istorinę valstybès vèliavą, kitų LDK parlamentarizmą liudijančių ženklų interjere jau nèra nèra - vadinas, prieš 500 metų diegta valdymo tradicija „nematoma“. Dèl kai kurių politikų reiškiamų priešingų nuostatų Seimo interjero pastoviojoje ekspozicijoje nebuvo įmanoma parodyti ir IV Seimo vaizdų, nors tai yra ittraukta ị interjero koncepciją. Seimo interjerui, kaip vientiso sumanymo projektui, igyvendinti nuolat trukdè subjektyvus - finansinio poreikio aspektas, nes šiai problemai spręsti tik $2003 \mathrm{~m}$. nebuvo „baiminamasi“ skirti lèšu. Autorius apibūdina tai kaip „subjektyvų“ veiksnị dèl to, kad parlamento vadovybès nepagrịstai baiminasi pritarti poreikiams, reikalingiems parlamento aplinkai kurti, nes neva gali sulaukti žiniasklaidos kritikos.

Aplinkos formavimui reikšminès įtakos turi Seimo vadovai ir Seimo kanceliarija, derinanti svarbiausius sprendimus. Daugiausia reikšmès ir išskirtinio dèmesio istorinio interjero formavimui, suvokdami tai kaip itin naudingą visuomenès savimonei informaciją, skyrè VII (1996-2000) ir VIII (2000-2004) metų Seimo vadovai (Seimo valdybos nariai). 


\section{Literatūra}

Berlin, I. Vienove ir įvairovè. Žvilgsniai i idèjų istoriją. Amžius, 1995, $447 \mathrm{p}$.

Dialogue among Civilizations. The Regional Summit Forum on Communication of Heritage: A New Vision of South East Europe. Opatija, Croatia, 31 May to 1 June 2006. Edited by F.W. (Russ) Russell. United Nations Educational, Scientific and Cultural Organization; Bureau of Strategic Planning, 2007.

Wilcox, D.L., Cameron, G.T., Ault, P.H., Agee, W.K. Ryšiai su visuomene: strategija ir taktika. Poligrafija ir informatika, 2007, - 496 p.

Drèma, V. Dingęs Vilnius. Vaga, 1991, - 407 p.

Gudavičius, E. Lietuvos istorija nuo seniausių laiku iki 1569 metų. Vilnius: Lietuvos rašytojų sąungos leidykla, Akad. skautų sąjūdžio Vydūno fondas Čikagoje, Kaunas: AB „Spindulys“, 1999.

Lietuvos istorija, IV tomas. Baltos lankos, 2009, 552 p.

Mitchell, W.J.T. Showing seeing: a critique of visual culture. Journal of visual culture. 2002, vol. 1, p. 165-180.

Mūsų konstitucionalizmo raida: straipsnių rinkinys. Vilnius, 2003. 


\title{
HERITAGE COMMUNICATION IN THE INTERIOR DESIGN OF THE SEIMAS: PROBLEMS OF SELECTION, DESIGN AND PRESENTATION OF SYMBOLS
}

\author{
ANDRIUS VAIŠNYS
}

\section{Summary}

Keywords: interior; communication; concept; parliamentarism; heritage; visualization.

After declaration of Independence by the Parliament of Lithuania in 1990 in the building constructed in 1976-1980, its environment and interior spaces, which usually are supposed to spread the history of the institution and spirit of the system have been undergoing changes rather slowly. The building constructed in the late seventies of the 20th C. was designed for the Supreme Council of the Lithuanian Soviet Socialist Republic (SSR), which used to be convened 2-3 times a year and imitated parliamentarism. In reality, it was an administrative building of the Praesidium of the Supreme Council and its servicing „apparatus“.

As late as in 1997 the first interior plan of the historic environment of the thencalled first palace was launched in order the walls of the parliament would spread the tradition of the Seimas of Lithuania, which dates back in the 15th Century - the period of the Great Duchy of Lithuania. In 2002, the Office of the Seimas included history experts into the development of the interior concept.

This article discusses the development of the present interior design of the par- liament building, actions that determined decisions in choosing the symbols in the development of Lithuania to mark the history of the parliament. The author also reveals the problems of decision making and attitude to the changes and perspectives of the interior design of the Seimas, communication of parliamentary heritage, as formation of a new visual documentary piece of work.

In terms of heritage communication, the historical interior design of the Seimas was born in this century as a new visual work, created based on various historical, political studies and documentary funds, which never directly targeted the object that interested the Seimas Office staff and heads of the parliament, i.e. parliamentarism. Construction of parliamentary tradition heritage provided a possibility not only to create „a concept of commemoration of the most prominent Lithuanian parliament members and events related with the Seimas of Lithuania“, which determined the decisions in 2000-2006 to commemorate parliament members and parliamentary events significant for the state of Lithuania also outside the par- 
liamentary building, elsewhere in Lithuania - now it should be considered as dissemination of parliamentarism idea. The same direction of such decisions could be maintained also in the future. The historical environment interior design of the building of the Lithuanian Seimas, which has been developed since 1997 following the consistent experts' concept, currently lacks uniform historical attitude: which significance is given to the parliaments of the Great Duchy of Lithuania, whether the contemporary parliament admits the role of parliamentary and other political activities of the elite of the Great Duchy of Lithuania, which is worth displaying in the working political environment.
Opposing opinions expressed by some politicians made displaying of images of the 4th Seimas (1936-1940) impossible in the permanent exposition of the Seimas interior, though they are included into the interior design concept.

Environment development is substantially influenced by the heads and office of the Seimas, coordinating the major decisions. Major importance and exclusive attention to historical interior design creation, understanding it as in particular important information for social consciousness, were granted by the heads of the 7th (1996-2000) and 8th (2000-2004) Seimas of the Republic of Lithuania (Seimas board members).

Iteikta $2012 \mathrm{~m}$. lapkričio $2 \mathrm{~d}$. 